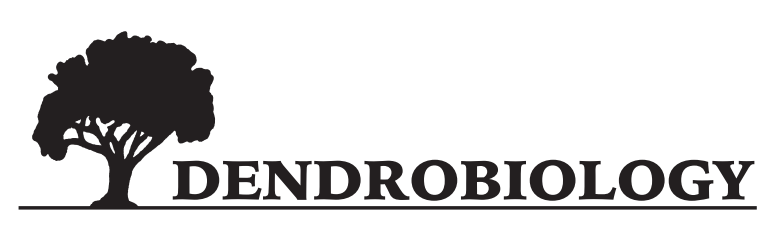

2021 , vol. $85,60-77$

https://doi.org/10.12657/denbio.085.007

\author{
Anna K. Jasińska, Beata Rucińska, Gregor Kozlowski, \\ Laurence Fazan, Giuseppe Garfi, Salvatore Pasta, Sébastien Bétrisey, \\ Emanuel Gerber, Krystyna Boratyńska, Adam Boratyński*
}

\title{
Taxonomic relationships and population differentiation of the south-western Eurasian Zelkova species inferred in leaf morphology
}

Received: 16 December 2020; Accepted: 19 February 2021

\begin{abstract}
The relict tree species Zelkova abelicea and Z. sicula (Ulmaceae) occur in Crete and Sicily, respectively. Zelkova abelicea grows in approximately 40 localities in the mountains of Crete, while $Z$. sicula has been found in only two stands in Sicily.

We compared 25 morphological characters of the leaves of both species and used statistical methods (Tukey's test, discrimination analysis, principal component analysis, agglomeration) to reveal the differences between these two species, their relation to Z. carpinifolia (the third Zelkova south-west Eurasian species), and between the leaves from different shoot types.

Our study represents the first comparative biometric analysis of the three Zelkova species localized in the western edge of the current geographic range of the genus. We found that the species differed from each other both, in terms of leaf form characters and level of leaf variation. Zelkova carpinifolia was clearly different from Z. abelicea, while the two populations of Z. sicula, SIB and SIA, were more similar to Z. carpinifolia and $Z$. abelicea, respectively. The latter finding supports the results of recent molecular studies suggesting the hybrid origin of $Z$. sicula.

Zelkova abelicea, Z. sicula and Z. carpinifolia differ each other in the leaf characteristics and level of phenotypic variation.
\end{abstract}

Keywords: biogeography, plant variation, relict trees, systematics, taxonomy, Ulmaceae

Addresses: A. K. Jasińska, K. Boratyńska, A. Boratyński, Institute of Dendrology Polish Academy of Sciences, Parkowa 5, 62-035 Kórnik, Poland, e-mail: borata@man.poznan.pl;

(1) AKJ https://orcid.org/0000-0003-4661-027X, (1) KB https://orcid.org/0000-0002-9325-1452,

(D) AB https://orcid.org/0000-0003-0678-4304

B. Rucińska, Kazimierz the Great University, Department of Botany, al. Ossolińskich 12,

85-093 Bydgoszcz, Poland

G. Kozlowski, L. Fazan, S. Bétrisey, Department of Biology and Botanic Garden, University of Fribourg, Chemin du Musée 10, CH-1700 Fribourg, Switzerland; (1) GK https://orcid.org/0000-0003-4856-2005,

(D) LF https://orcid.org/0000-0002-2981-1806

G. Kozlowski, E. Gerber, Natural History Museum Fribourg, Chemin du Musée 6, CH-1700 Fribourg, Switzerland

G. Kozlowski, Shanghai Chenshan Plant Science Research Center, Chinese Academy of Sciences, Shanghai Chenshan Botanical Garden, 3888 Chenhua Road, Songjiang, Shanghai 201602, China G. Garfi, S. Pasta, National Research Council (CNR), Institute of Biosciences and BioResources, Corso Calatafimi 414, I-90129 Palermo, Italy; (1) GG https://orcid.org/0000-0003-0466-4288,

(1) SP https://orcid.org/0000-0003-3265-9072

*Corresponding author 


\section{Introduction}

The genus Zelkova includes six species, the three in the Eastern Asia (Z. serrata (Thun.) Makino, Z. sinica C. K. Schneid. and Z. schneideriana Hand.-Mazz.), and three (Z. carpinifolia (Pall.) K. Koch, Z. abelicea (Lam.) Boiss. and Z. sicula Di Pasq., Garfi \& Quézel) in the western part Asia and eastern Mediterranean region (Kozlowski \& Gratzfeld, 2013; Kozlowski et al., 2014). The East-Asiatic species and Euxino-Hyrcanian Z. carpinifolia occurs in the mesic climate (Prilipko, 1961; Browicz \& Zieliński, 1982; Kozlowski \& Gratzfeld, 2013), whilst Mediterranean Z. abelicea and $Z$. sicula live under typical Mediterranean climate conditions, the later with long-lasting summer hot and dry period (Rivas-Martínez et al., 2004). Due to their rarity and conservation status, both insular species are threatened in their natural ranges. According to IUCN red list criteria, $Z$. abelicea is considered endangered (EN), while $Z$. sicula is critically endangered (CR) (Garfi et al., 2017; Kozlowski et al., 2018).

Zelkova abelicea can grow as a tree up to $15 \mathrm{~m}$ high or as a shrub, the latter habit frequently resulting from browsing disturbance (Sarlis, 1987; Christensen, 1997; Fazan et al., 2012). It is found in isolated populations on the five mountain ranges of Crete, between 800 and $1800 \mathrm{~m}$ a.s.l., mostly on calcium-rich soils issuing from Triassic metamorphic limestone (Søndergaard \& Egli, 2006; Goedecke \& Bergmeier, 2018). Its distribution extends up to the supra-Mediterranean climate belt (Rivas-Martínez et al., 2004). The lowermost known localities are on north-facing rocky slopes, while the uppermost stands on south-facing slopes (Bosque et al., 2014; Kozlowski et al., 2014; Goedecke \& Bergmeier, 2018). The long-lasting isolation of the populations living in the different mountain massifs appears the main cause of their current genetic differentiation (Christe et al., 2014; Naciri et al., 2019). The global population of $Z$. abelicea include approximately 20,000 fructifying trees mostly concentrated in the Lefka Ori (West Crete) (Kozlowski et al., 2014).

Zelkova sicula grows as a shrub of 3-4 (max 8$) \mathrm{m}$ high and potentially as a small tree. It is known from two localities where it survives forming two different clonal populations (Garfi et al., 2017), both of them probably having a hybrid origin (Christe et al., 2014). The two populations occur mostly along the bottom of seasonal streams that dry out during summers, between 320 and $525 \mathrm{~m}$ a.s.l., respectively (Garfi et al., 2011), in the thermo-Mediterranean climate belt (Rivas-Martínez et al., 2004). Some individuals form flowers and fruits, but they do not produce viable seeds, so the species regenerates only by root suckering (Garfi et al., 2017).

Leaves of trees are basic from the taxonomic point of view (Krüssmann, 1962), despite their relatively high level of variation and susceptibility to influence of environmental conditions (e.g. Marcysiak, 2012a, b, c; Pérez-Harguindeguy et al., 2013). The leaves of plants living in mesic regions are as a rule larger and have thinner epidermis and mesodermis layers, comparing to plants leaving in more xeric regions (Krüssmann, 1962; Lakusic et al., 2010; Zhong et al., 2014). The leaf blade length, width and shape, the number of marginal teeth and secondary veins are species specific, but influenced by their function and position on the vegetative versus reproductive shoots and position within tree crown (Mejnartowicz, 1972; Wójcicki, 1997; Wang et al., 2001; Jasińska et al., 2015). The leaf size and shape of specimens exposed to the animal browsing are different when compare to the leaves from undamaged specimens (Zieliński \& Güner, 2000; Denk \& Grimm, 2005; Kozlowski \& Gratzfeld, 2013).

In the genus Zelkova, the leaf morphology represents a set of key diagnostic characters, providing basic elements in studies on phylogeny and biogeography (Denk \& Grimm, 2005). The species can be distinguished based on fruit and leaf characters
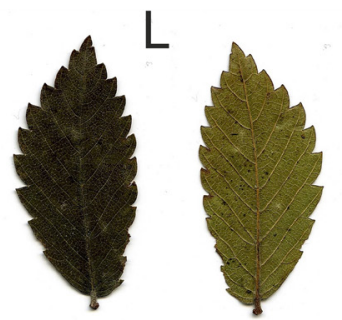

Zelkova carpinifolia
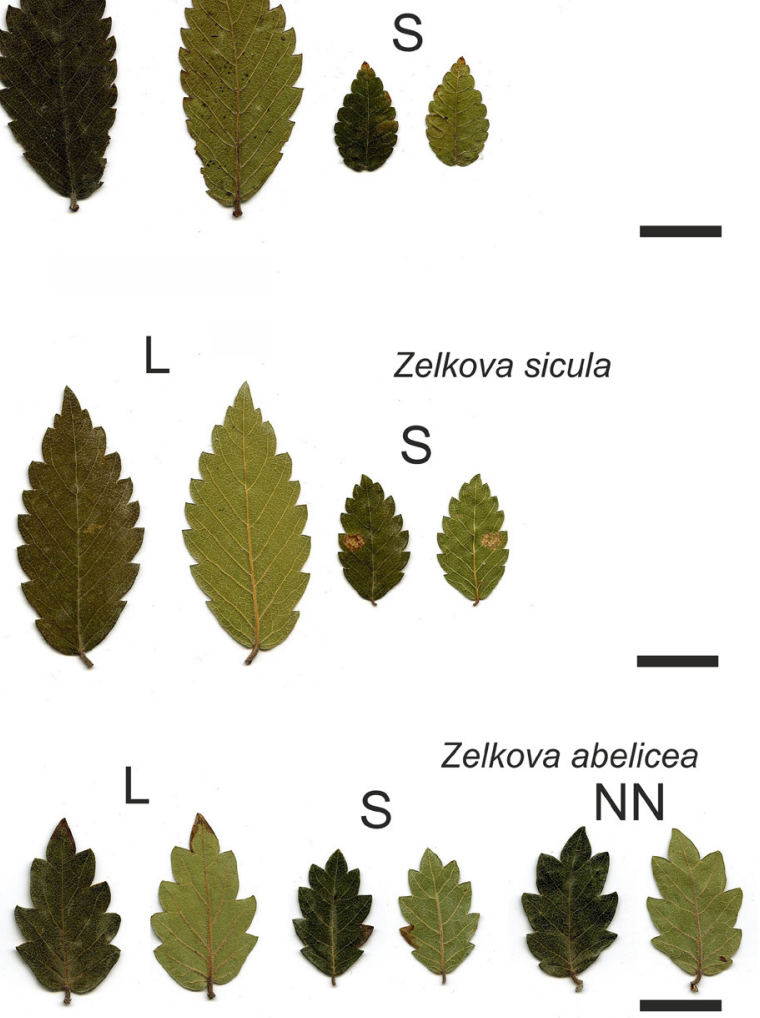

\section{Zelkova sicula}

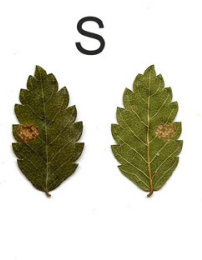

Fig. 1. Scanned leaves of Zelkova carpinifolia, Z. sicula and $Z$. abelicea: $\mathrm{L}-$ leaves from vegetative shoots, $\mathrm{S}$ - leaves from fertile shoots, $\mathrm{NN}$ - leaves of $Z$. abelicea from non fruiting trees; in left column adaxial (upper) and in right column abaxial (underside) leaf surface in every leaf category; bar $=2 \mathrm{~cm}$ 
(Quézel et al., 1993; Wang et al., 2001; Fu et al., 2003; Kozlowski \& Gratzfeld, 2013). However, except for Z. carpinifolia (Jasińska et al., 2015), so far investigations and comparative analyses based on leaf morphometry have not yet been conducted. The Zelkova leaves from sterile/vegetative shoots have been usually described as different than those of fertile/fruiting twigs (Fig. 1). The first are usually larger than the latter, and are more regularly serrated (Denk \& Grimm, 2005; Rucińska, 2012; Jasińska et al., 2015). However, when considered individually, leaves from vegetative shoots of one species can be sometimes confused with the leaves of fertile shoots of another species. Also, leaves from individuals impacted by external disturbances (e.g. browsing) can even pose problems of taxonomic misidentification. This is the case of most populations of $Z$. abelicea, where permanent browsing induces the prevalence of extremely small and deformed leaves.

Based on the morphological characters of $Z$. carpinifolia used by Jasińska et al. (2015), we compared the all three south-western Eurasian species of Zelkova in the aim to: (1) point out leaf characteristics discriminating among species, (2) evaluate the possible compliance of fruiting and vegetative shoots, from one species to another and (3) outline the geographical and taxonomic patterns of morphological differentiation among the three investigated species and the possible consistency with findings issuing from the genetic investigations (e.g. Christe et al., 2014).

\section{Material and methods}

\section{Plant material and measurement}

We analyzed both known populations of $Z$. sicula and 11 populations of $Z$. abelicea. From fruiting trees, leaves were collected separately from sterile longshoots (L) and fertile dwarf-shoots (S). In case of lack of fruiting specimens of $Z$. abelicea, the non-fruiting, possibly browsed trees were also sampled. In this case, the leaves from not injured parts of tree crowns were gathered without distinguishing between types of shoots (NN). From each individual, up to 10 leaves per shoot-type were sampled (Table 1). All the material was collected from the sunny side of the tree crowns, 1-3 $\mathrm{m}$ above ground level, from the central parts of the twigs. The leaves were pressed, dried as herbarium material, and conserved in this state until measurement. Data on Z. carpinifolia from Jasińska et al. (2015) were included in the analyses for comparison. In total, 3325 leaves from 361 individuals representing 20 populations were analyzed (Fig. 2).

A number of leaf characteristics with diagnostic/discriminant value were selected, including 16 simple traits (e.g. blade length and width, number of teeth and secondary veins, angle of leaf blade apex and base, etc.) and 9 proportional characters (e.g. length/width ratio, number of nerves/number of teeth ratio, asymmetry of leaf blade, etc; see Table 2 for the complete list and codes and electronic supplementary materials, Fig. S1 for some details).

Table 1. Studied populations of Z. sicula, Z. abelicea and Z. carpinifolia

\begin{tabular}{|c|c|c|c|c|c|c|c|}
\hline Species & Locality & Code & $\mathrm{N}$ & $\begin{array}{c}\text { Leaf type } \\
\text { (number of leaves) }\end{array}$ & $\begin{array}{c}\text { Longitude E } \\
{\left[^{\circ}\right]}\end{array}$ & $\begin{array}{c}\text { Latitude } \mathrm{N} \\
{\left[^{\circ}\right]}\end{array}$ & $\begin{array}{l}\text { Altitude } \\
{[\mathrm{m}]}\end{array}$ \\
\hline \multirow[t]{2}{*}{ Z. sicula } & Italy, Sicily 1 & SIA & 9 & $\mathrm{~L}(75), \mathrm{S}(90)$ & 14.861 & 37.171 & 510 \\
\hline & Italy, Sicily 2 & SIB & 12 & $\mathrm{~L}(117), \mathrm{S}(119)$ & 15.045 & 37.210 & 330 \\
\hline \multirow[t]{11}{*}{ Z. abelicea } & Greece, Lefka Ori, Omalos 1 & OMA1 & 20 & $\mathrm{NN}(200)$ & 23.912 & 35.316 & 1231 \\
\hline & Greece, Lefka Ori, Omalos 2 & OMA2 & 10 & L(99), S(100) & 23.903 & 35.309 & 1265 \\
\hline & Greece, Lefka Ori, Ambelitsias 1 & AMB1 & 20 & $\mathrm{NN}(200)$ & 23.986 & 35.367 & 1269 \\
\hline & Greece, Lefka Ori, Ambelitsias 2 & AMB2 & 3 & $L(20), S(26)$ & 23.981 & 35.355 & 1429 \\
\hline & Greece, Lefka Ori, Niato & NIA & 22 & $\mathrm{NN}(220)$ & 24.155 & 35.288 & 1221 \\
\hline & Greece, Psiloritis, Mt. Kedros & KED1 & 9 & $\mathrm{~L}(90), \mathrm{S}(88)$ & 24.627 & 35.188 & 1293 \\
\hline & Greece, Psiloritis, Mt. Kedros & KED2 & 3 & $\mathrm{NN}(30)$ & 24.627 & 35.188 & 1293 \\
\hline & Greece, Psiloritis, Rouvas & PSI & 7 & $\mathrm{NN}(70)$ & 24.929 & 35.179 & 1334 \\
\hline & Greece, Lasithi, Kéfala 1 & LAS1 & 3 & $\mathrm{~L}(30), \mathrm{S}(30)$ & 25.538 & 35.170 & 1196 \\
\hline & Greece, Lasithi, Kéfala 2 & LAS2 & 3 & $\mathrm{NN}(29)$ & 25.538 & 35.170 & 1196 \\
\hline & Greece, Thripiti, Afentis Stavromenas & STA & 20 & $\mathrm{NN}(200)$ & 25.888 & 35.081 & 1151 \\
\hline \multirow[t]{7}{*}{ Z. carpinifolia* } & Turkey, Trabzon & TRA & 7 & S & 39.866 & 40.950 & 76 \\
\hline & Georgia, Ajametis Nature Reserve & ANR & 20 & $\mathrm{~L}, \mathrm{~S}$ & 42.763 & 42.143 & 150 \\
\hline & Georgia, Vani & VAN & 16 & $\mathrm{~L}, \mathrm{~S}$ & 42.565 & 42.089 & 100 \\
\hline & Georgia, Babaneuri Nature Reserve & $\mathrm{BAB}$ & 17 & $\mathrm{~L}, \mathrm{~S}$ & 45.371 & 42.081 & 470 \\
\hline & Azerbaijan, Xabulan & $\mathrm{XAN}$ & 10 & $\mathrm{~L}, \mathrm{~S}$ & 48.800 & 38.661 & 40 \\
\hline & Azerbaijan, Parakand & PAR & 10 & $\mathrm{~L}, \mathrm{~S}$ & 48.803 & 38.650 & 40 \\
\hline & Azerbaijan, Güneshli (Z. hyrcana) & GUN & 10 & L, S & 48.469 & 38.805 & 650 \\
\hline
\end{tabular}

* after Table 1 in Jasińska et al. (2015).

$\mathrm{N}$ - number of sampled individuals; leaf-types collected from fructifying individuals: L vegetative shoot, $\mathrm{S}$ fertile shoot; NN - leaf collected from non-fructifying individuals. 


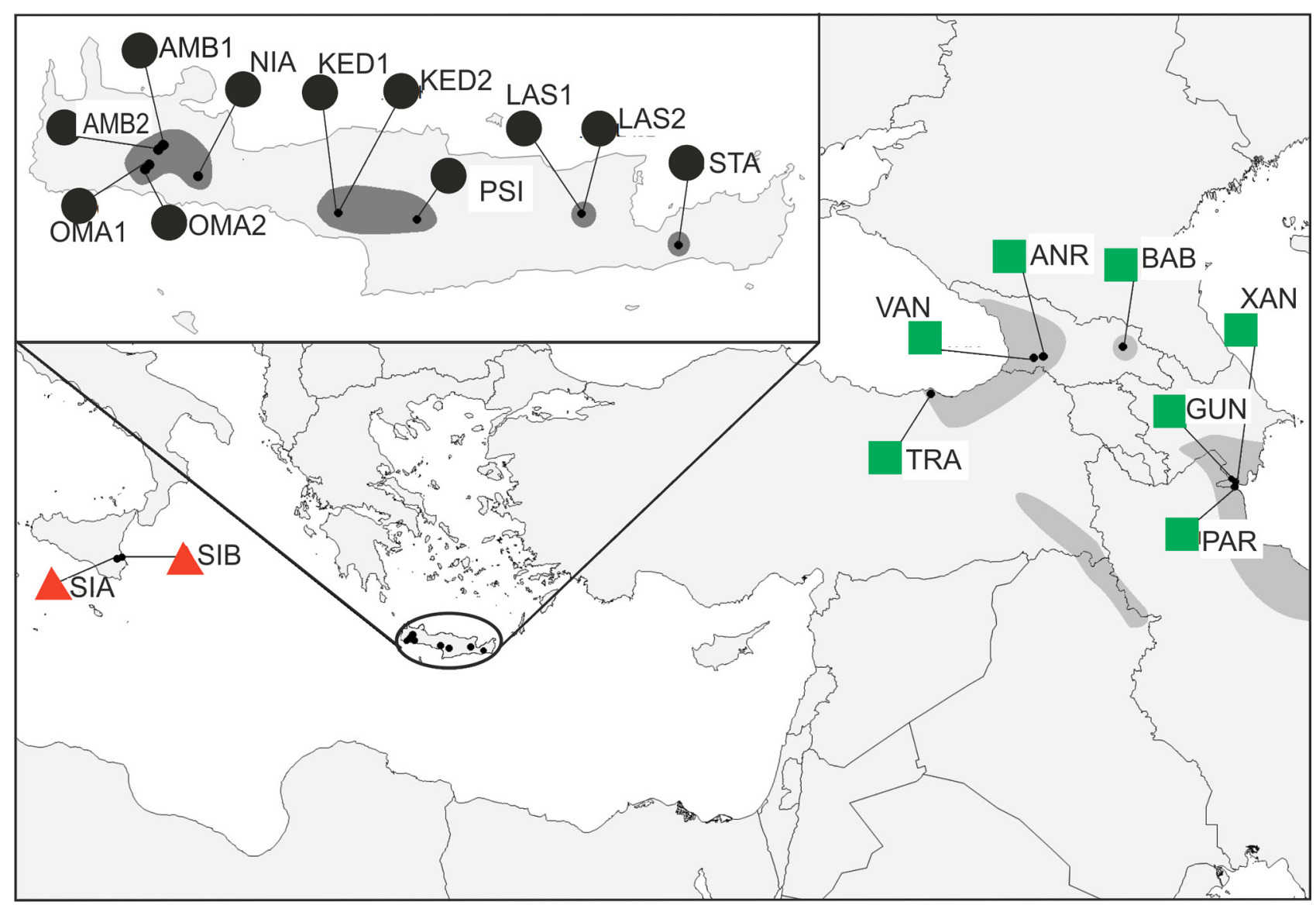

Fig. 2. Geographic distribution of studied populations of Zelkova carpinifolia, Z. abelicea and Z. sicula (acronyms as in Table 1); shaded - area of distribution of Z. carpinifolia in Asia (after Browicz \& Zieliński 1982a, simplified) and Z. abelicea on Crete (after Kozlowski \& Gratzfeld 2013, simplified)

Leaf characteristics were measured on scanned images, following the method described in Jasińska et al. (2015). Measurements were performed on scanned images using WinFolia software (Regent Instrument).

\section{Statistics}

The statistical distribution of each leaf character was assessed for data symmetry and unimodality using the Shapiro-Wilk test (Shapiro \& Wilk, 1965). Data with skewed distributions were log-transformed. The homoscedasticity of variances was verified using the Brown-Forsythe test to ensure the appropriateness of parametric statistical tests in multivariate analyses (Zar, 1999; Sokal \& Rohlf, 1995).

Possible interactions between characters were determined using Pearson's correlation coefficient (Garren, 1998). The differences in the mean values of characters between populations and species were tested using Tukey's post hoc honestly significant differences $T$-test and the $t$-test for independent samples with Cochran-Cox correction for non-homogeneous variances (Zar, 1999; Sokal \& Rohlf, 1995; Stanisz, 2007). The similarities among species, populations and leaves based on L-, S- and NN-types of shoots were evaluated using a discrimination function analysis followed by agglomeration with Ward's method on the Euclidean and Mahalanobis distances (Sokal \& Rohlf, 1995; Stanisz, 2007).

The proportional characters (LA, PV, W_1, W_2, AP, LBW, DI, and LS, see Table 2), the simple traits not included within the recalculated characters (AA, $\mathrm{AB}$ ) and the traits important for the differentiation between species (BL, BW, TN) were used in the multivariate analyses. All other characters were excluded due to their strong correlations with each other $(\mathrm{r} \leq|0.95|)$. The data were standardized before analyses (Sokal \& Rohlf, 1995). STATISTICA 9 PL software (StatSoft Poland, Kraków) was used for calculations.

To evaluate the geographical and morphological multi-character relationships among populations and species, the Mantel test (Mantel, 1967) was performed between the matrices of Mahalanobis and geographical distances using the software Barrier 2.2 (Manni et al., 2004) and PopTools v. 3.2.5 (Hood, 2010). The geographical distances between populations were determined using MapInfo Professional 10.5 PL software (Pitney Bowes) based on their geographic coordinates. 


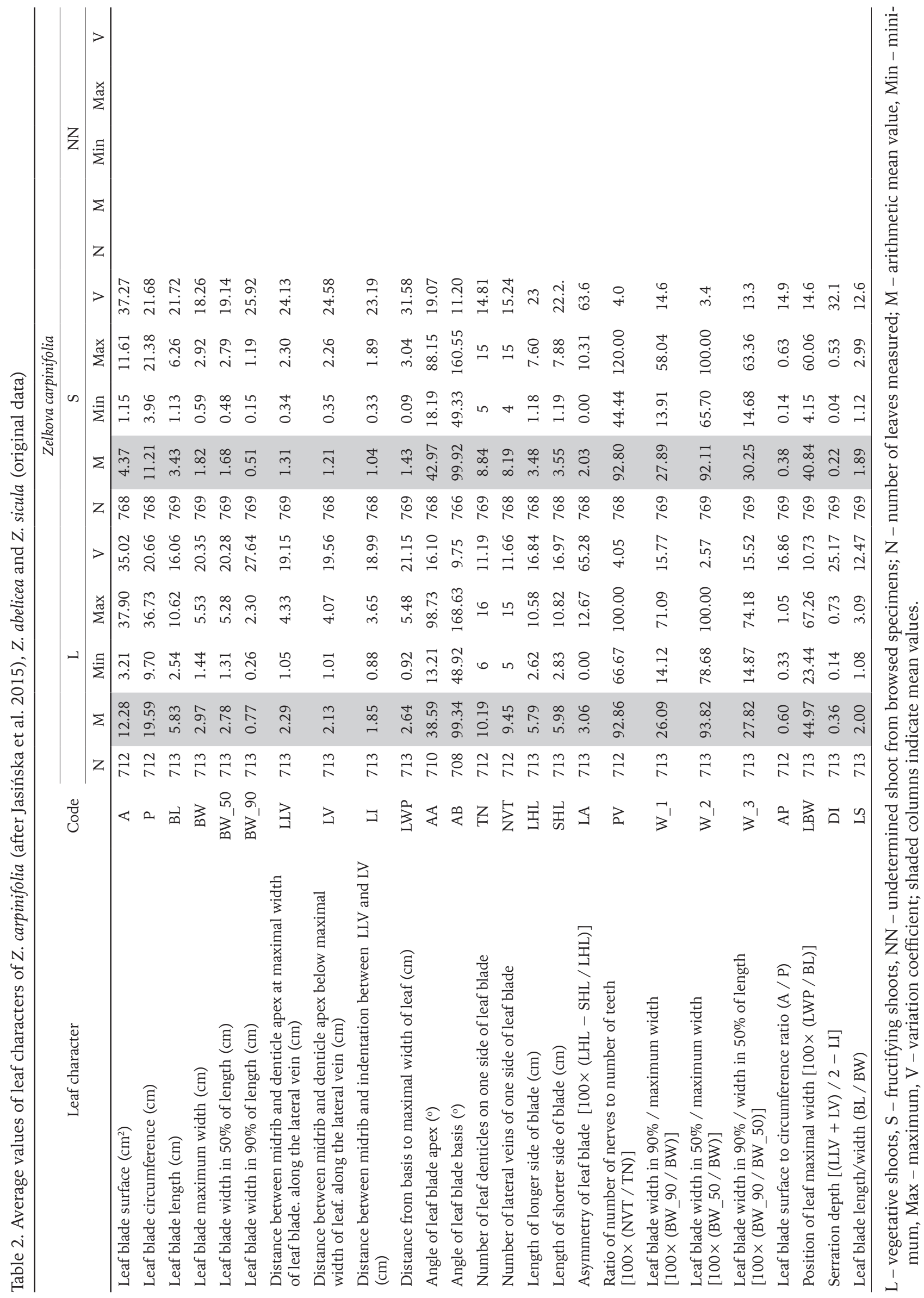




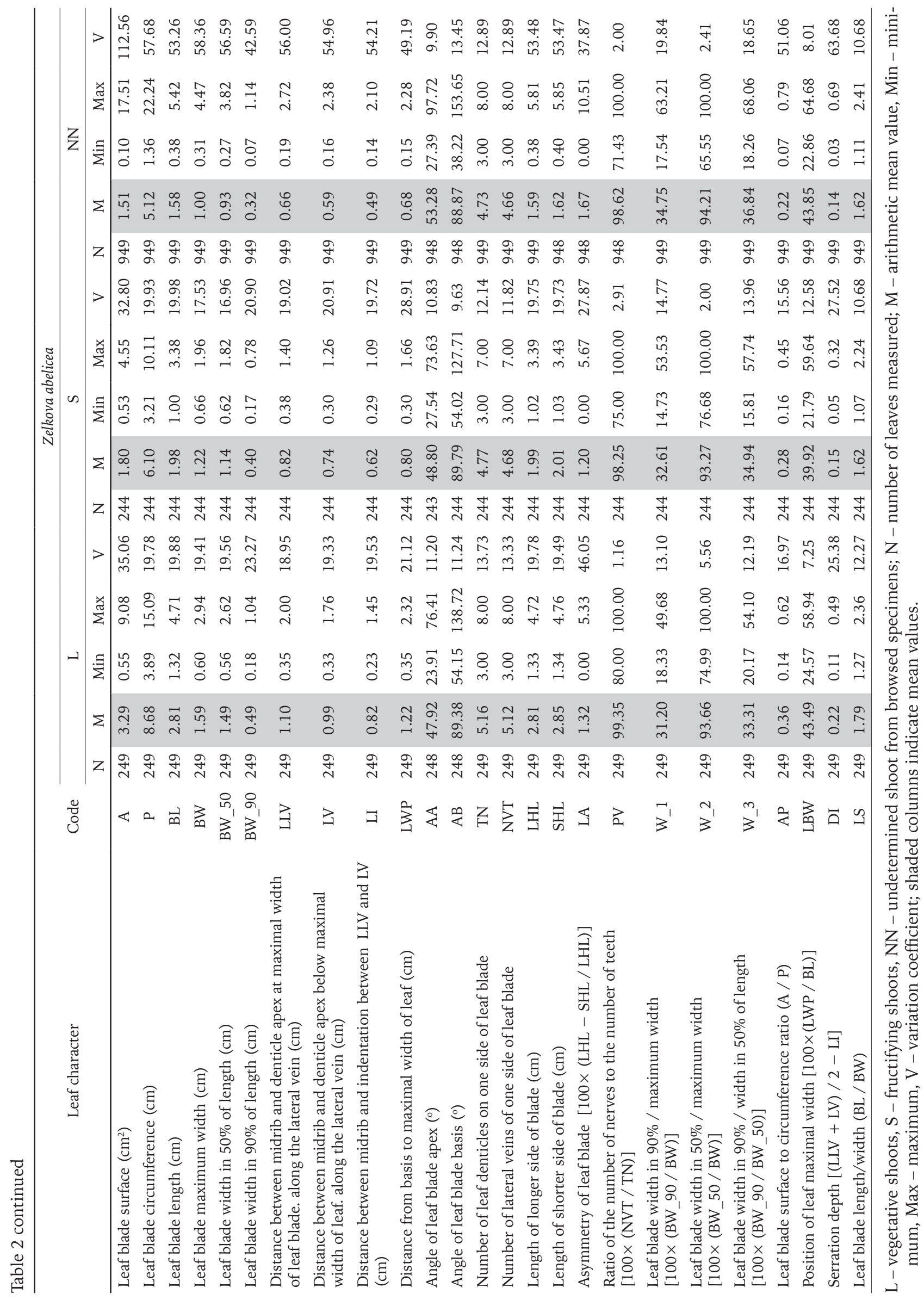




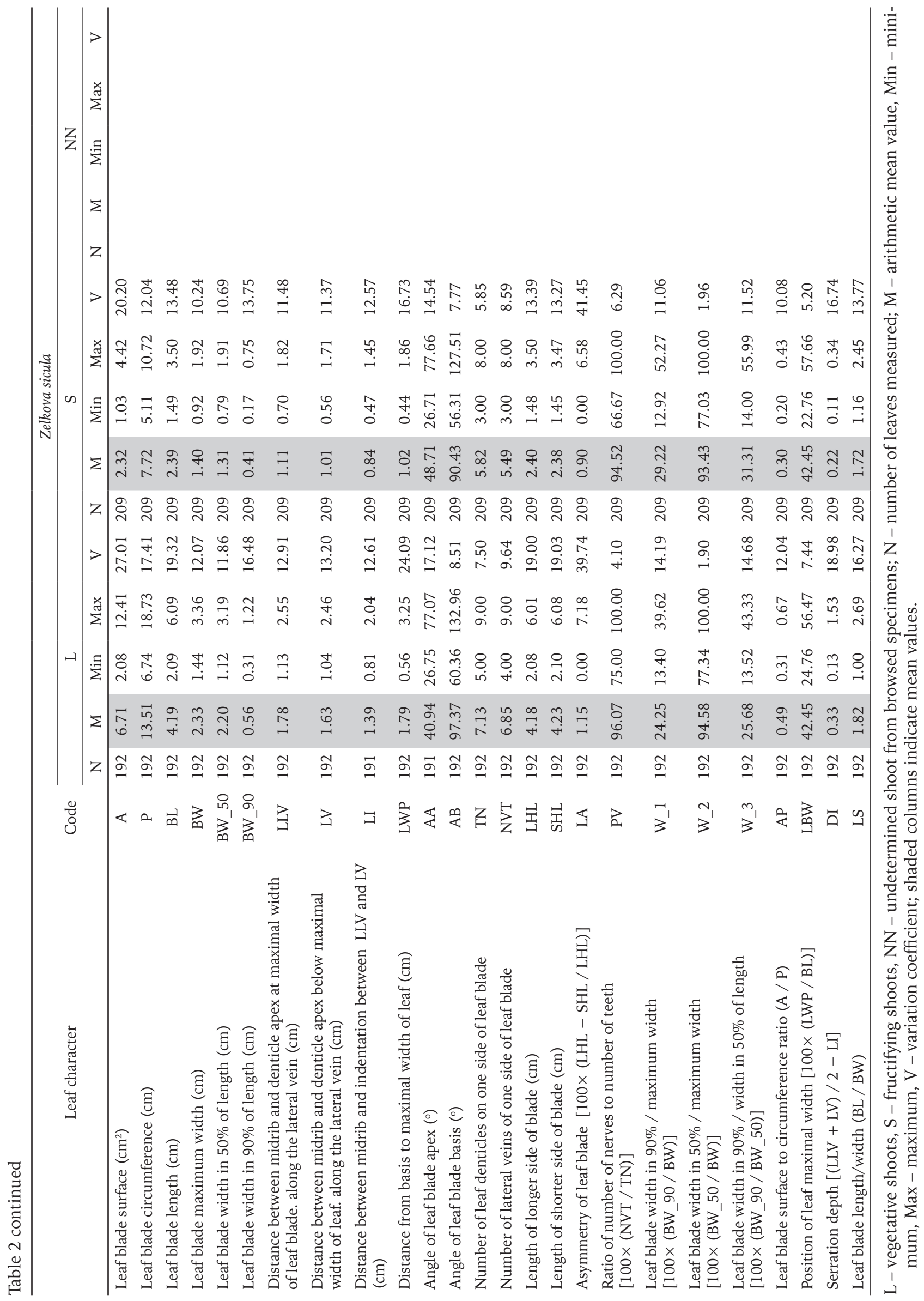




\section{Results}

\section{Variation and correlation of characters}

Most of the leaf characters showed normal or nearly normal distributions and homoscedastic variances. Non-normal distributions (Shapiro-Wilk test, $\mathrm{P} \leq 0.01)$ were found for a few characters and populations (electronic supplementary materials, Table S1). The unimodality, normal distribution, and homoscedasticity of the variances of most data after transformation and standardization allowed the application of the multivariate analyses.

Among species, morphological variation was the lowest in Z. sicula for the leaves of both L- and S-type shoots, and the highest in Z. carpinifolia. At the species level, the S-type leaves of $Z$. sicula were less variable than the L-type leaves. The characters of the NNtype leaves of $Z$. abelicea were the most variable, with coefficients of variation generally more than twice as high as those of the S- and L-type leaves (Table 2). The most variable characters in all species and types of shoots $(\mathrm{V}>25 \%)$ were the blade surface (LA), and asymmetry (A) in Z. abelicea and Z. carpinifolia. The lowest level of variation $(\mathrm{V}<7-10 \%)$ concerned the nerve/teeth ratio (PV) and the blade/width ratios (W_2 and LBW) in every species (Table 2).
Most of the characters describing the size of the leaf blade, as well as the number of veins and teeth, were significantly correlated in the L- and S-type leaves in every species, as well as in the NN-type leaves of $Z$. abelicea. These variables were also positively correlated when the L-type and S-type leaves of all species were taken into account together (Supplementary material, Table S2). In the L- and S-type leaves of every species, the strongest correlations $(r=0.95-1.00)$ were detected in each of the possible combinations between pairs related to blade size (A, P, BL, BW, BW_50) and margin (LLV, LV and LI). Consequently, the individual characters from these pairs were omitted in the multivariate analyses as redundant.

\section{Differences between L-, S- and NN-type leaves}

The leaves from L-type shoots were significantly $(\mathrm{P}<0.01)$ larger than those from S-type (Table 3). PV was the only character that did not differ between L-type and S-type leaves in every species. AB was similar in the two types of leaves in $Z$. carpinifolia and $Z$. abelicea, as were LA and W_2 in Z. abelicea and Z. sicula. A lack of differences between L- and S-type

Table 3. Level of differences between L-, S- and NN-types of leaves within Z. carpinifolia (after Jasińska et al. 2015), Z. abelicea and $Z$. sicula detected in the t-Student test; differences significant at $\mathrm{p} \leq 0.01$ bolded; character codes as in Table 2

\begin{tabular}{|c|c|c|c|c|c|c|c|c|c|c|c|c|}
\hline \multirow{2}{*}{$\begin{array}{c}\text { Character } \\
\text { code }\end{array}$} & \multicolumn{3}{|c|}{ Z. carpinifolia } & \multicolumn{6}{|c|}{ Z. abelicea } & \multicolumn{3}{|c|}{ Z. sicula } \\
\hline & $\mathrm{L}$ & $S$ & $\mathrm{P}_{\mathrm{L} / \mathrm{S}}$ & $\mathrm{L}$ & $S$ & NN & $\mathrm{P}_{\mathrm{L} / \mathrm{S}}$ & $\mathrm{P}_{\mathrm{L} / \mathrm{NN}}$ & $\mathrm{P}_{\mathrm{S} / \mathrm{NN}}$ & $\mathrm{L}$ & $S$ & $\mathrm{P}_{\mathrm{L} / \mathrm{S}}$ \\
\hline $\bar{A}$ & 12.28 & 4.48 & 0.0000 & 3.29 & 1.81 & 1.51 & 0.0000 & 0.0000 & 0.1548 & 6.64 & 2.32 & 0.0000 \\
\hline $\mathrm{P}$ & 19.60 & 11.21 & 0.0000 & 8.68 & 6.12 & 5.12 & 0.0000 & 0.0000 & 0.0116 & 13.39 & 7.72 & 0.0000 \\
\hline $\mathrm{BL}$ & 5.83 & 3,42 & 0.0000 & 2.81 & 1.98 & 1.58 & 0.0000 & 0.0000 & 0.0009 & 4.14 & 2.39 & 0.0000 \\
\hline BW & 2.97 & 1.82 & 0.0000 & 1.59 & 1.23 & 1.00 & 0.0000 & 0.0000 & 0.0024 & 2.33 & 1.40 & 0.0000 \\
\hline BW_50 & 2.78 & 1.68 & 0.0000 & 1.49 & 1.45 & 0.93 & 0.0000 & 0.0000 & 0.0021 & 2.20 & 1.31 & 0.0000 \\
\hline BW_90 & 0.77 & 0.51 & 0.0000 & 0.49 & 0.40 & 0.32 & 0.0019 & 0.0000 & 0.0010 & 0.56 & 0.41 & 0.0000 \\
\hline LLV & 2.29 & 1.31 & 0.0000 & 1.10 & 0.82 & 0.66 & 0.0000 & 0.0000 & 0.0020 & 1.77 & 1.11 & 0.0000 \\
\hline LV & 2.13 & 1.22 & 0.0000 & 0.99 & 0.74 & 0.59 & 0.0000 & 0.0000 & 0.0015 & 1.63 & 1.01 & 0.0000 \\
\hline LI & 1.85 & 1.04 & 0.0000 & 0.82 & 0.63 & 0.49 & 0.0000 & 0.0000 & 0.0003 & .38 & 0.84 & 0.0000 \\
\hline LWP & 2.64 & 1.43 & 0.0000 & 1.22 & 0.80 & 0.68 & 0.0000 & 0.0000 & 0.0393 & 1.76 & 1.02 & 0.0000 \\
\hline $\mathrm{AA}$ & 38.59 & 42.97 & 0.0001 & 47.90 & 49.03 & 53.28 & 0.4599 & 0.0000 & 0.0010 & 41.43 & 48.69 & 0.0019 \\
\hline $\mathrm{AB}$ & 99.34 & 99.92 & 0.7153 & 89.31 & 89.85 & 88.91 & 0.8374 & 0.8675 & 0.6588 & 98.04 & 90.41 & 0.0027 \\
\hline $\mathrm{TN}$ & 10.19 & 8.84 & 0.0000 & 5.16 & 4.78 & 4.73 & 0.0409 & 0.0087 & 0.7275 & 7.10 & 5.82 & 0.0000 \\
\hline NVT & 9.45 & 8.19 & 0.0000 & 5.12 & 4.68 & 4.66 & 0.0157 & 0.0039 & 0.8510 & 6.82 & 5.49 & 0.0000 \\
\hline LHL & 5.79 & 3.48 & 0.0000 & 2.81 & 1.99 & 1.59 & 0.0000 & 0.0000 & 0.0010 & 4.13 & 2.38 & 0.0000 \\
\hline SHL & 5.98 & 3.55 & 0.0000 & 2.85 & 2.02 & 1.62 & 0.0000 & 0.0000 & 0.0013 & 4.17 & 2.40 & 0.0000 \\
\hline LA & 3.06 & 2.03 & 0.0001 & 1.32 & 1.20 & 1.67 & 0.3829 & 0.0161 & 0.0000 & 1.18 & 0.90 & 0.0403 \\
\hline PV & 92.86 & 92.80 & 0.9192 & 99.35 & 99.12 & 98.62 & 0.0542 & 0.0210 & 0.4102 & 95.93 & 94.55 & 0.3815 \\
\hline W_1 & 26.09 & 27.89 & 0.0042 & 31.19 & 32.71 & 34.75 & 0.2373 & 0.0016 & 0.0941 & 24.20 & 29.23 & 0.0000 \\
\hline W_2 & 93.82 & 92.11 & 0.0001 & 93.67 & 93.30 & 94.21 & 0.5417 & 0.3161 & 0.0430 & 94.53 & 93.42 & 0.0527 \\
\hline W_3 & 27.82 & 30.25 & 0.0002 & 33.31 & 35.03 & 36.84 & 0.1812 & 0.0016 & 0.1400 & 25.64 & 31.32 & 0.0000 \\
\hline $\mathrm{AP}$ & 0.60 & 0.38 & 0.0000 & 0.36 & 0.29 & 0.22 & 0.0000 & 0.0000 & 0.0000 & 0.49 & 0.30 & 0.0000 \\
\hline LBW & 44.97 & 40.84 & 0.0000 & 43.48 & 39.99 & 43.85 & 0.0053 & 0.6129 & 0.0011 & 42.15 & 42.46 & 0.7193 \\
\hline DI & 0.36 & 0.22 & 0.0000 & 0.22 & 0.15 & 0.14 & 0.0000 & 0.0000 & 0.2916 & 0.32 & 0.22 & 0.0000 \\
\hline LS & 2.00 & 1.89 & 0.0048 & 1.79 & 1.62 & 1.62 & 0.0033 & 0.0012 & 0.8953 & 1.79 & 1.72 & 0.3988 \\
\hline
\end{tabular}




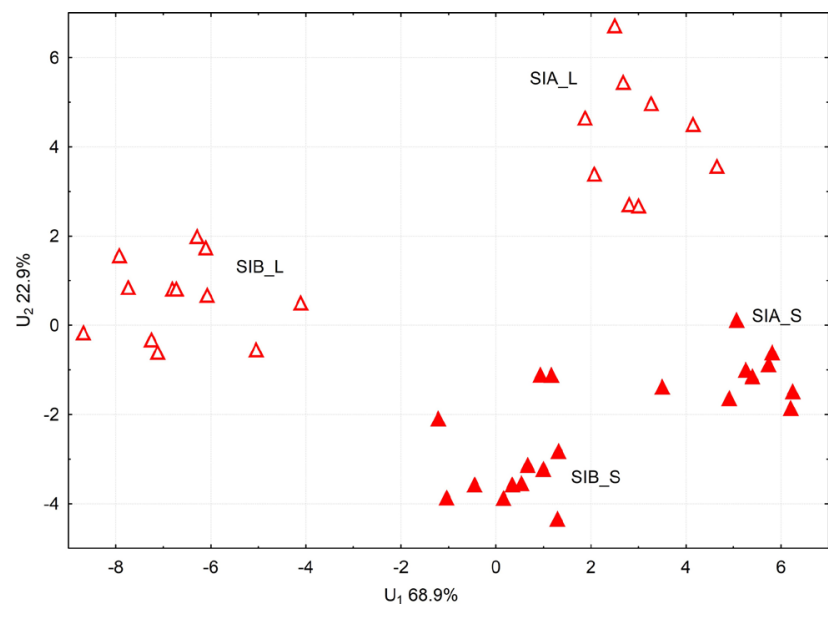

Fig. 3. Differentiation of individuals from the two populations (SIA and SIB) of Zelkova sicula based on the comparison between the leaves from vegetative shoots (SIA_L, SIB_L) and fertile shoots (SIA_S, SIB_S)
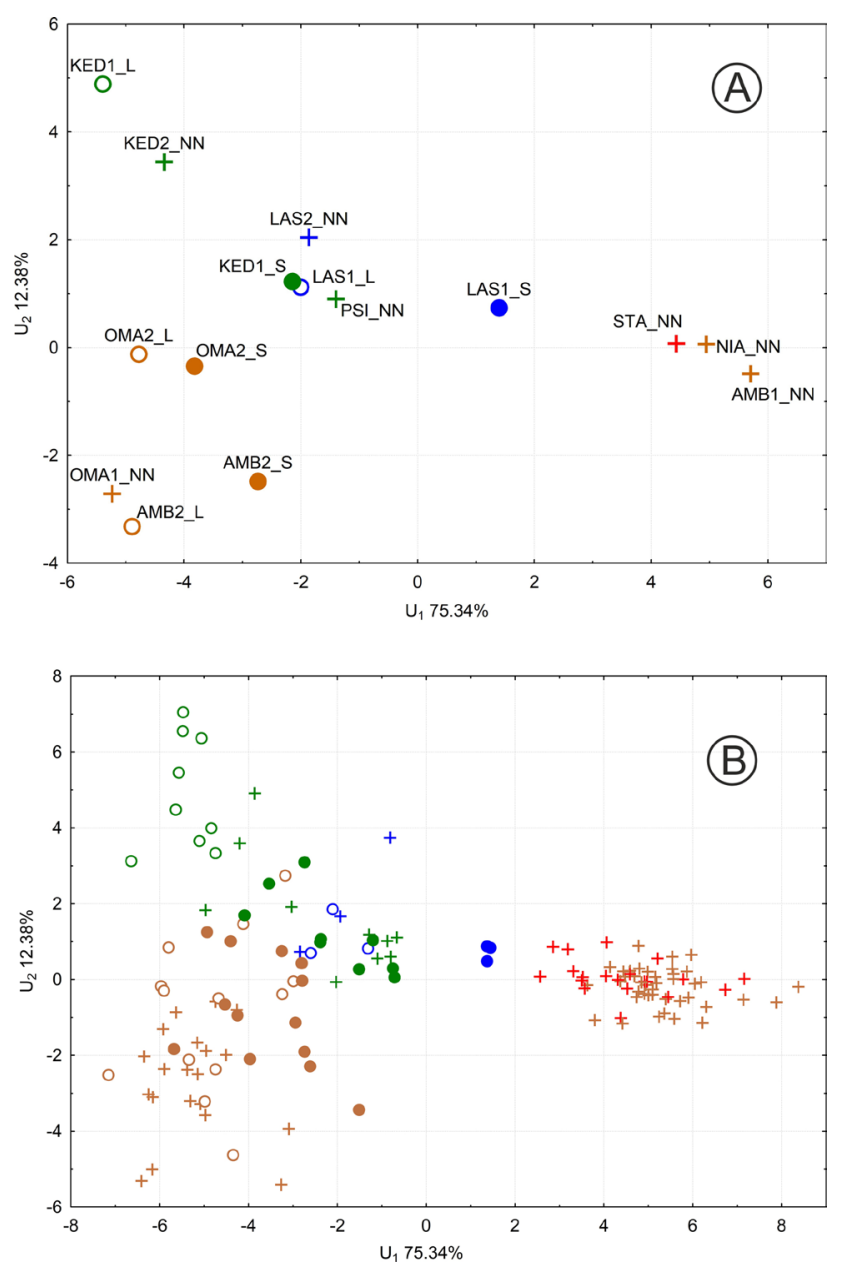

Fig. 4. Differentiation of populations (A) and individuals (B) of Z abelicea based on the comparison between the leaves from vegetative shoots $(\mathrm{L}, \mathrm{O})$, fertile shoots $(\mathrm{S}, \bullet)$ and non-fruiting individuals $(\mathrm{NN},+)$; population acronyms as in Table 1; samples from Lefka Ori (Omalos, Ambelitsias, Niato) in brown, Psiloritis (Kedros, Rouvas) in green, Lasithi (Dikti Oros, Kefala) in blue, Thripiti (Afentis Stavromenas) in red leaves was detected in 9 characters for $Z$. abelicea, 5 characters for $Z$. sicula, and only 2 characters in $Z$. carpinifolia. The leaves sampled from non-fruiting individuals of $Z$. abelicea (NN-type) were more different from the L-type leaves (20 characters different at $\mathrm{P} \leq 0.01)$ than from the S-type leaves (12 characters different at $\mathrm{P} \leq 0.01$, Table 3 ).

In $Z$. sicula, the highest discrimination power between individuals was observed for basic traits related to leaf blade size and proportion (BL, LS, AP), and edge (TN), with partial Wilks' $\lambda$ values of 0.30 , $0.61,0.69$ and 0.68 , respectively. The leaves specifically representing either L-type or S-type shoots formed different groups in the space between the first two discrimination variables, and the individuals formed compact groups (Fig. 3). $U_{1}$ was responsible for nearly $70 \%$ of the total variation, while $\mathrm{U}_{2}$ contributed for about $23 \%$; here too, both axes were mainly affected by basic characters associated to blade size and edge (respectively BL, AA, LS, DI, and BW, AP, BL).

Within $Z$. abelicea, the level of difference between L- and S-type leaves was lower than in Z. sicula. NNtype leaves were dispersed between L- and S-type leaves when collected from the same populations. Additionally, the NIA, STA and AMB_1 populations, represented exclusively by $\mathrm{NN}$-type leaves, were well separated from all the others (Fig. 4A). The first two discrimination variables accounted for more than $87 \%$ of the total variation and both were largely determined by blade width (BW) and blade edge (DI) features. The individuals on the scatter plot formed rather dispersed groupings reflecting the distribution at population level. The few individuals represented by L- and NN-type leaves were positioned at the margins of the cloud and were separated from those of the individuals represented by S-type leaves (Fig. 4B).

\section{Differences among species}

Most of the characters revealed species-specific mean values and, to a lesser degree, differed between populations within species. Despite differences, the ranges of character variation overlapped (Table 2). Student's $t$-test with Cochran-Cox correction and Kruskal-Wallis tests detected statistically significant $(\mathrm{P} \leq 0.01)$ differences between pairs of species for most of leaf characters and between the majority of the possible combinations of species and leaf types. The lowest number of differences was found in W_2 and LBW (3 and 4 differences, respectively). On the other hand, A, P, BL, BW, BW_50, LWP, TN, NVT, LHL and SHL differed at statistically significant levels $(\mathrm{P} \leq 0.01)$ between all possible pairwise species and leaf-type combinations (Table 4). The species with the fewest significantly different characters were $Z$. abelicea L-type and $Z$. sicula S-type leaves. 
Table 4. Results of Student's t test and Kruskal-Wallis tests: P-level of differences between leaf characters of $Z$. carpinifolia (CAR), Z. abelicea (ABE) and Z. sicula (SIC) depending on the leaf type (L, S or NN); differences significant at $\mathrm{p} \leq 0.01$ bolded; character codes as in Table 1

\begin{tabular}{|c|c|c|c|c|c|c|c|c|c|c|c|c|c|c|c|c|}
\hline \multirow{2}{*}{$\begin{array}{c}\text { Character } \\
\text { code }\end{array}$} & \multicolumn{5}{|c|}{ CAR_L } & \multicolumn{5}{|c|}{ CAR_S } & \multicolumn{2}{|c|}{ ABE_L } & \multicolumn{2}{|c|}{ ABE_S } & \multicolumn{2}{|c|}{ ABE_NN } \\
\hline & BE_L & ABE_S & ABE_NN & SIC_L & SIC_S & ABE_L & ABE_S & ABE_NN & SIC_L & SIC_S & SIC_L & SIC_S & SIC_L & SIC_S & SIC_L & SIC_S \\
\hline A & 0.00 & 0.00 & 0.00 & 00 & 0.00 & 0.00 & 0.00 & 0.00 & 0.00 & 0.00 & 0.00 & 0.00 & 0.00 & 0.00 & 0.00 & 0.00 \\
\hline+ & & & & & & & & & & & & & & & 00 & \\
\hline BL & & & & 00 & & & & & 0 & 00 & 00 & 0.00 & 00 & 0 & 00 & .00 \\
\hline BW & & 00 & & 0.00 & 0.00 & & & & 0.00 & 0.00 & 0.00 & 0.01 & 00 & 0.00 & 0.00 & 0.00 \\
\hline & & & & 00 & 0.00 & & & & 00 & 0.00 & 00 & 0.01 & .00 & .00 & .00 & 0.00 \\
\hline & & & & 0.00 & 0.00 & & & & 0.04 & 0.00 & 0.03 & 0.00 & 0.00 & 0.69 & 0.00 & 0.01 \\
\hline & & & & & & & & & & & & & & & 0 & \\
\hline LV & & & & & & & & & 0.00 & 0.00 & 0.00 & 0.69 & 0.00 & 0.00 & 0.00 & 0.00 \\
\hline LI & & & & 0.00 & 0.00 & & & & 0.00 & 0.00 & 0.00 & 0.61 & 0.00 & .00 & 00 & 0.00 \\
\hline & & & & 00 & 0.00 & & & & 0.00 & 0.00 & 0.00 & 0.00 & .00 & 0.00 & .00 & 0.00 \\
\hline AA & & & & & & & & & 9 & 0.00 & 0.00 & 0.68 & 0.00 & 0.86 & 0.00 & 0.01 \\
\hline $\mathrm{AB}$ & & & & & 0 & & & & & 0.00 & 0.00 & 0.66 & 0.00 & 0.81 & 0.00 & 0.45 \\
\hline 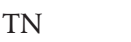 & & & & 0.00 & 0. & & & & 0 & 0.00 & 0.00 & 0.00 & 0.00 & 0.00 & 0.00 & 0.00 \\
\hline & & & & & 0. & & & & 0 & 0.00 & 0.00 & 0.04 & 00 & 0 & .00 & 0.00 \\
\hline & & & & 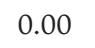 & & & & & مחم & 0.00 & 0.00 & 0.00 & 0.00 & 0.00 & 0.00 & 0.00 \\
\hline & & & & & & & & & & & & & & & & \\
\hline LA & & & & 0.00 & 0.00 & & 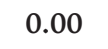 & & 0.00 & 0.00 & 0.38 & 0.01 & 0.88 & 0.01 & 0.00 & 0.00 \\
\hline PV & & & & 0.00 & & & & & 0.00 & 0.21 & 0.00 & 0.00 & 0.04 & 0.02 & 0.01 & 0.01 \\
\hline W_1 & & & & 0.04 & 0.00 & & & & 0.00 & 0.11 & 0.00 & 0.08 & 0.00 & 0.01 & 0.00 & 0.00 \\
\hline & & & & & & & & & & 0.01 & 0.17 & 0.69 & 0.03 & 0.83 & 0.48 & 0.09 \\
\hline W_3 & & 00 & 00 & 0.03 & 0.00 & 0.00 & 0.00 & 00 & 0.00 & 0.24 & 0.00 & 0.09 & 0.00 & 0.01 & 0.00 & 0.00 \\
\hline $\mathrm{AP}^{-}$ & & & & & & & & & & 0.00 & 0.00 & 0.00 & 0.00 & 0.36 & 0.00 & 0.00 \\
\hline LBY & & 0.00 & & 0.00 & 0.02 & 0.00 & 0.47 & 0.00 & 0.16 & 0.04 & 0.16 & 0.20 & 0.08 & 0.03 & 0.04 & 0.03 \\
\hline DI & & & & 0.03 & & & & & 0.00 & 0.86 & 0.00 & 0.72 & 0.00 & 0.00 & 0.00 & 0.00 \\
\hline LS & 00 & 0.00 & .00 & 0.00 & 0.00 & 0.05 & 0.00 & 0.00 & 0.14 & 0.00 & 0.98 & 0.29 & 0.02 & 0.11 & 0.02 & 0.09 \\
\hline
\end{tabular}

Zelkova carpinifolia populations appeared to be the most distinct from those of $Z$. abelicea and $Z$. sicula, regardless of the leaf character. On the contrary, Z. abelicea showed no evident distinctions among L-type, S-type and NN-type leaves. Only some populations represented by exclusive NN-type leaves (NIA, STA and AMB1) were separated from the other populations (Fig. 5A). Both populations of $Z$. sicula, when represented by $S$-type leaves, were placed between populations of $Z$. carpinifolia and $Z$. abelicea closer to the later species. However, when $Z$. sicula was represented by L-type of leaves, it was separated from $Z$. carpinifolia and $Z$. abelicea. With respect to the discriminant variable $\mathrm{U}_{1}$ (responsible for approximately $70 \%$ of the total variation), samples from L-type shoots of $Z$. sicula were more similar to the $Z$. carpinifolia S-type leaves, whereas those from S-type shoots resembled leaves from $Z$. abelicea L-type shoots (Fig. 5A). Conversely, with concern to the discriminant variable $\mathrm{U}_{2}$ (explaining about $10 \%$ of the total variation) all samples of $Z$. sicula resembled leaves of $Z$. abelicea. The variable $\mathrm{U}_{1}$ was determined mostly by BL, TN, AP, BW, DI, AA, W_1, LS, AB and LA; interestingly, variance in $U_{2}$ was explained by a sub-sample of the same characters (TN, DI, AP, W_1 and $\mathrm{BW})$.
The discrimination between individuals showed greater dispersion and distinctness among $Z$. carpinifolia trees than among $Z$. abelicea trees, independently on the leaf type (Fig. 5B). The individuals of $Z$. sicula also formed a dispersed group, but 22 individuals predominantly represented by L-type shoots from the SIB population entered the $95 \%$ confidence interval of $Z$. carpinifolia, while 7 individuals of $Z$. sicula entered the $95 \%$ confidence interval of $Z$. abelicea. The latter specimens of $Z$. sicula were represented by S-type leaves and were mostly sampled from the SIA population.

The agglomeration of the populations based on Mahalanobis distances according to Ward's method revealed a prominent separation of all populations of $Z$. carpinifolia based on L-type leaves, which formed the most distant group (Fig. 5C). The second group of populations was not homogenous and consisted of three sub-groups. The first one was composed of populations of $Z$. abelicea, including six populations with NN-type leaves, two with L-type leaves and one with S-type leaves. The second subgroup included populations of $Z$. carpinifolia based on S-type leaves, with the exception of TRA and BAB. The third subgroup was the most heterogeneous at the species level and comprised six populations of $Z$. abelicea (three based on S-type, two on L-type and one on NN-type 

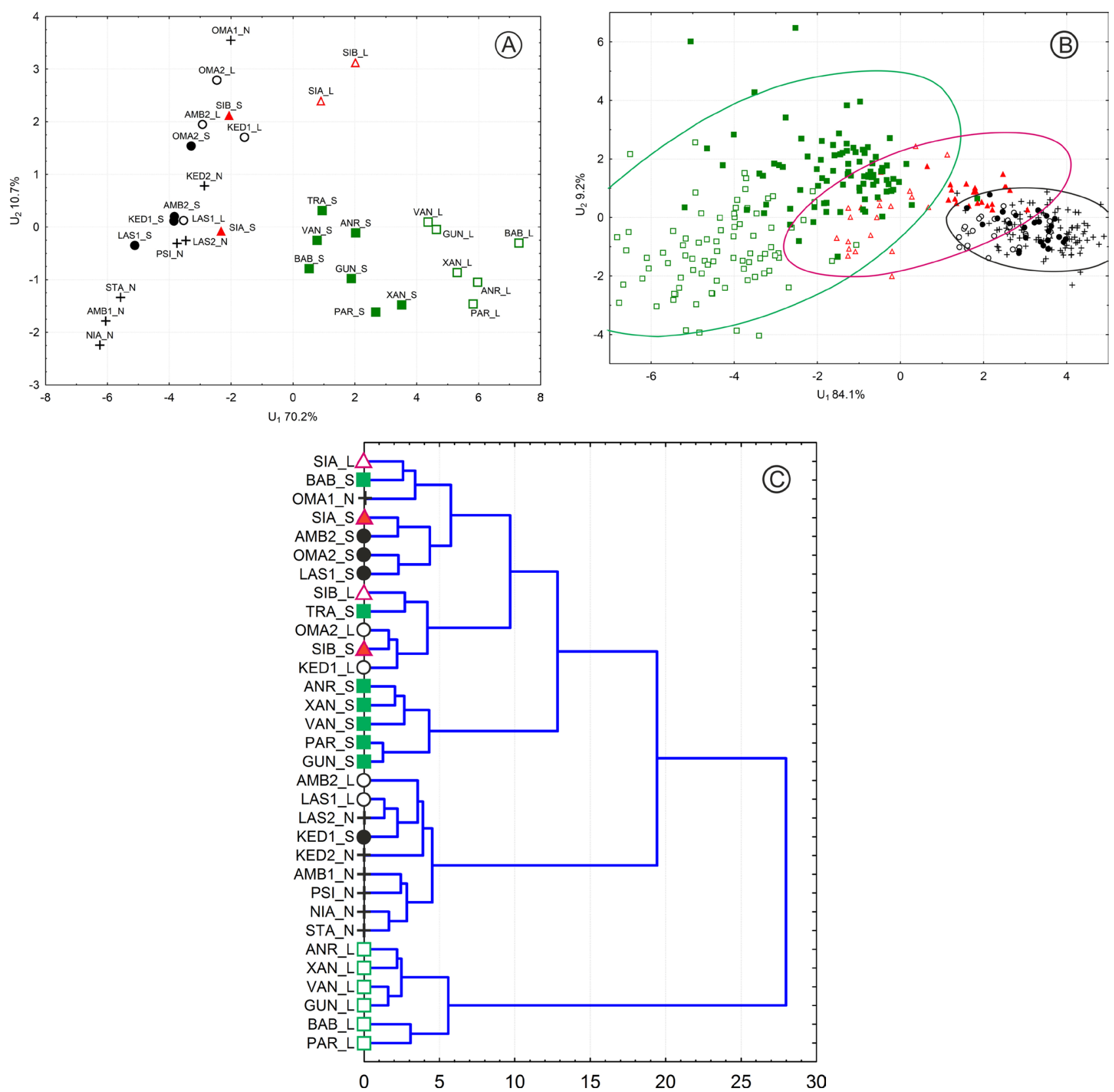

Fig. 5. Differentiation of the populations of Zelkova carpinifolia, Z. abelicea and Z. sicula based on L-, S- and NN-shoot leaves: Z. carpinifolia: L-type, S-type; Z. abelicea: L-type, S-type, + - NN-type; Z. sicula: L-type, S-type (population acronyms as in Table 1); A: discrimination between populations, B: discrimination between individuals; C: agglomeration of the populations based on the Euclidean distances

shoots), two populations of $Z$. carpinifolia with S-type leaves, and all populations of $Z$. sicula.

For the L-type leaves, the intermediate position of the $Z$. sicula SIA population between $Z$. carpinifolia and Z. abelicea was visible on the scatter plots between the possible combinations of $\mathrm{U}_{1}$ and $\mathrm{U}_{2}$ with the discriminant variable $\mathrm{U}_{3}$, while SIB was placed separately. The variable $\mathrm{U}_{4}$ also resulted in a separate position for Z. sicula (Fig. S2).

The analysis of Mahalanobis and geographic distances based on L-type leaves showed that the main geographic barrier (a) was surprisingly between the two known populations of $Z$. sicula, the next two barriers separated respectively the Mediterranean and the Transcaucasian species (b), and the two Mediterranean insular relicts (c) (Fig. 6). On the basis of S-type leaves, the stronger separation (a) was between $Z$. carpinifolia and the two Mediterranean relatives, the next (b) was again, interestingly, between the two populations of $Z$. sicula, and the third (c) distinguished between the Colchic and the Hyrcanian populations of $Z$. carpinifolia. 


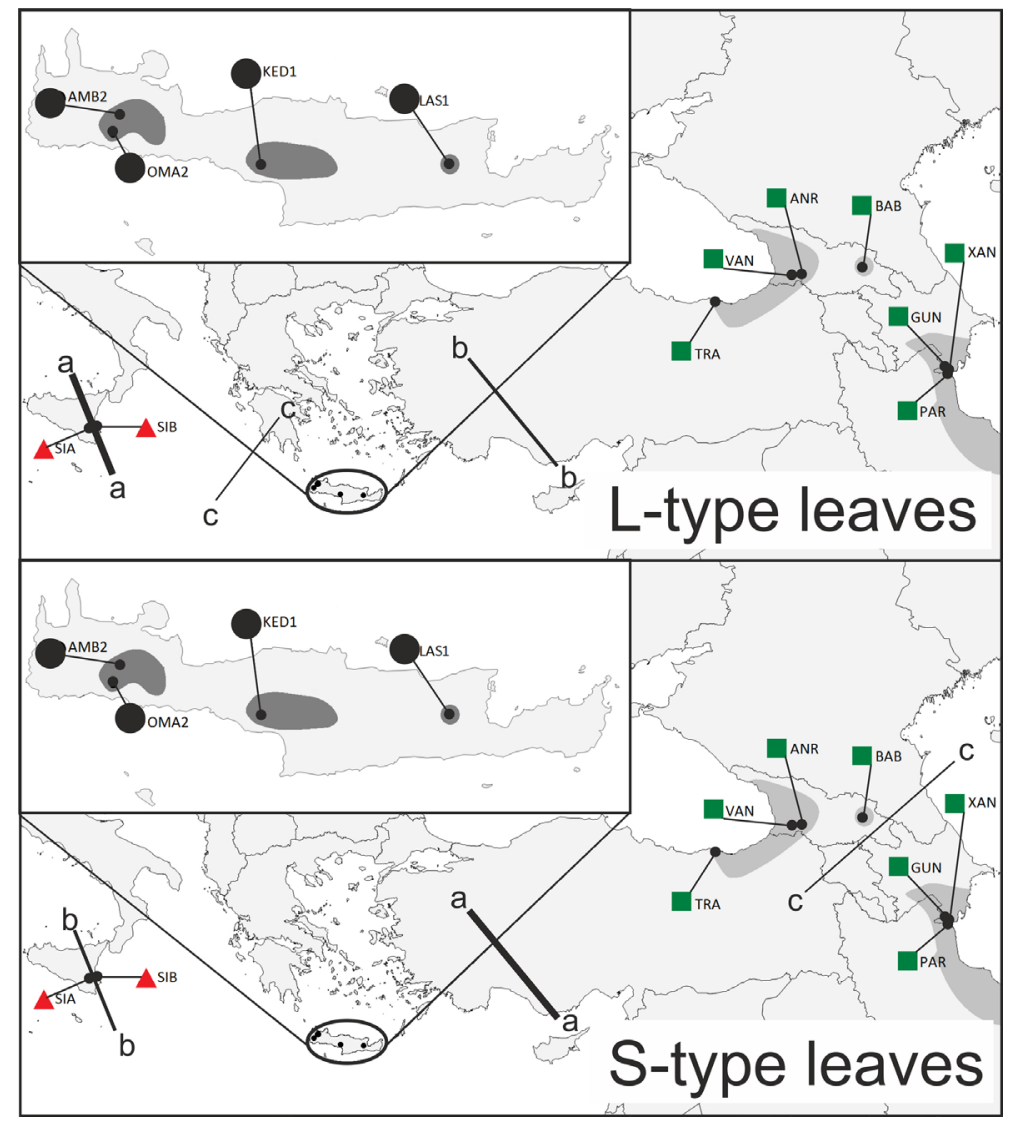

Fig. 6. Morphological barriers between sampled populations from the data on L- and S-type of leaves, detected using Barrier 2.2 of the Mahalanobis' distances between populations; thickness of the lines corresponds to the importance of the barrier: the thickest (a) represent the most important barriers, and the thinnest lines (c) represent the least important barriers; population acronyms as in Table 1

\section{Discussion}

\section{Value of leaf morphometric analyses within the genus Zelkova}

Our study represents the first biometrical comparison of all the three south-west Eurasian Zelko$v a$ species made on a broad range of material and a large set of leaf characters. So far, only a few basic leaf characters have been included in the description of Zelkova species (Tutin, 1964; Zieliński, 1979; Browicz \& Zieliński, 1982b; Christensen, 1997), mainly concerning leaf length (our BL) and leaf width (our $\mathrm{BW}$ ), and sometimes the number of secondary veins (NTV) and the number of teeth (TN) (Table 5). With respect to the data reported in the literature, our data usually appeared less variable. These differences may issue from the more standardized procedure of plant material collection, we adopted with respect to previous measurements. Our data came from a large amount of leaves sampled from the central parts of the shoots, from parts of tree crowns exposed to the sun, which reduced the level of their variation. Conversely, the literature data were likely based on limited herbarium specimens and may not have distinguished between L- and S-type leaves. Additionally, the majority of herbarium specimens are most often collected from the best-developed, 'nicest' tree twigs, which consequently provided larger leaves. The higher minimal values found in our data probably resulted from omission of leaves from the basal parts of the shoots.

When describing the leaves, we used several additional characters that have not been reported before. We present many data on leaf blade size and their edge (A, P, BL, BW, LLV, LV, LI, LWP, AA, AB, TN, NVT, DI) and certain characters calculated as proportions. Such data hitherto have been published only for Z. carpinifolia (Jasińska et al., 2015) but are original for $Z$. sicula and $Z$. abelicea. These results may be valuable in the determination of fossil materials, including those belonging to extinct taxa. For instance, based on only a few morphological traits Nakagawa et al. (1998) suggested to ascribe to Z. sicula or its ancestor fossil remains originally reported as $Z$. carpinifolia. Thus, our analytical approach may reduce uncertainty, providing useful additional information for the reliable reconstruction of the spatial-temporal differentiation in Zelkova in the Mediterranean regions and south-western Asia. 
Table 5. Average values and range of variation of BL, BW, NVT and TN of Zelkova carpinifolia (after Jasińska et al., 2015, simplified), Z. abelicea and Z. sicula issuing from the present study (bolded), compared to literature data; character codes as in Table 1

\begin{tabular}{|c|c|c|c|c|c|}
\hline Species & $\mathrm{BL}[\mathrm{cm}]$ & $\mathrm{BW}[\mathrm{cm}]$ & NVT & TN & Source of data \\
\hline \multirow[t]{11}{*}{ Z. carpinifolia } & $4-6$ & & & & Grossheim, 1930 \\
\hline & $4-8$ & $2-4$ & $4-8$ & & Lozina-Lozinskaya, 1951 \\
\hline & $(1.5-) 2-3.5(4.6)$ & & $(4-) 6-7(-9)$ & & Prilipko, 1961 \\
\hline & to $10-12$ (S shoot) & & & & Prilipko, 1961 \\
\hline & $(1.5-) 2-8(-9)$ & $(1-) 1.5-4(-4.5)$ & $6-10(-12)$ & & Browicz \& Zieliński, 1982b \\
\hline & to $8(-10)$ & to $4(-4.5)$ & & & Zieliński, 1979 \\
\hline & $2-5(-6)$ & $(0.8-) 1.5-2(-2.5)$ & & & Anşin \& Gerçek, 1991 \\
\hline & & & (3-) 6-12 & & Wang et al., 2001 \\
\hline & & & to 12 & & Denk \& Grimm, 2005 \\
\hline & $5.83(2.54-10.62)$ & $2.97(1.44-5.53)$ & $9.45(5-15)$ & $10.19(6-16)$ & L shoot \\
\hline & $3.43(1.13-6.26)$ & $1.82(0.59-2.92)$ & $8.19(4-15)$ & $8.84(5-15)$ & S shoot \\
\hline \multirow[t]{12}{*}{ Z. abelicea } & $1.2-2.5$ & & & & Krüssmann, 1962 \\
\hline & to 2.5 & & & $7-9$ & Tutin, 1964 \\
\hline & $(0.6-) 1-4(-4.8)$ & $(0.4-) 0.7-3(-4.3)$ & $(3-) 4-6(-7)$ & & Christensen, 1997 \\
\hline & $1-5$ & $0.5-3.5$ & & $6-8$ & Quézel et al., 1993 \\
\hline & $1-3.5$ & $0.5-2.5$ & & $3-6$ & Di Pasquale et al., 1992 \\
\hline & $2-5$ & & & $7-9$ & Sarlis, 1987 \\
\hline & $1-5$ & $0.5-2.5$ & & $3-6$ & Søndergaard \& Egli, 2006 \\
\hline & & & $3-8$ & & Wang et al., 2001 \\
\hline & & & $<10$ & & Denk \& Grimm, 2005 \\
\hline & $2.81(1.32-4.71$ & $1.59(0.60-2.94)$ & $5.12(3-8)$ & $5.16(3-8)$ & L shoot \\
\hline & $1.98(1.00-3.38)$ & $1.22(0.66-1.96)$ & $4.68(3-7)$ & $4.77(3-7)$ & S shoot \\
\hline & $1.58(0.38-5.42)$ & $1.00(0.33-4.47)$ & $4.66(3-8)$ & $4.73(3-8)$ & NN shoot \\
\hline \multirow[t]{4}{*}{ Z. sicula } & $1-3$ & $0.5-2.5$ & & $3-6$ & Quézel et al., 1993 \\
\hline & $2.7(1-5)$ & $1.8(0.5-5)$ & & $5-8$ & Di Pasquale et al., 1992 \\
\hline & $4.19(2.09-6.09)$ & $2.33(1.44-3.36)$ & $6.85(4-9)$ & $7.13(5-9)$ & L shoot \\
\hline & $2.39(1.49-3.50)$ & $1.40(0.92-1.92)$ & $5.49(3-8)$ & $5.82(3-8)$ & S shoot \\
\hline
\end{tabular}

\section{Differences among leaf types and their ecological significance}

One main result of our study is, that as in $Z$. carpinifolia (Jasińska et al., 2015, Fig. 3), also in the two Mediterranean species the leaves from the vegetative long shoots are significantly larger, than those from fruiting shoots. This feature is indeed characteristic of every Zelkova species (Kozlowski \& Gratzfeld, 2013) and is also found in many other tree species (Jentys-Szaferowa, 1970; Staszkiewicz, 1997, and literature cited herein). However, in $Z$. abelicea differently than in the other two species, the strongest distinction was observed not at level of shoot-type but rather among populations (Figs. 2AC). This particularity could mirror the life-history of each population and/or the remarkable environmental gradient characterizing the whole distribution range of the Cretan species. As a matter of fact, the western populations host the majority of plants with a normal tree habit (Kozlowski et al., 2014), whose leaves can develop free from browsing disturbance. This condition allows the "normal" development of the leaf blades, preserving the features typical for the species in term of size and proportional traits.
Additionally, the western populations can enjoy of more mesic-humid climate, progressively shifting towards a significant increase of dryness at the easternmost side of the island (Goedecke \& Bergmeier, 2018). In tree species, this environmental pattern usually associates with a general decrease of leaf size and related characters (Marcysiak, 2012a, b, c; Pérez-Harguindeguy et al., 2013). Therefore, it can be suggested that when different leaf-types from such diverse populations are compared all together, the influence of population distinctiveness may prevail on the value of the diagnostic traits at shoot type level.

In many taxa, the leaves from vegetative shoots are more variable than leaves from fructifying shoots (Jentys-Szaferowa, 1970; Staszkiewicz, 1997). Actually, this pattern was revealed for Z. sicula, and had also been described in previous researches for $Z$. carpinifolia (Lozina-Lozinskaya, 1951; Wang et al., 2001; Denk \& Grimm, 2005; Jasińska et al., 2015). It is also worth mentioning that though the S-, L- and $\mathrm{NN}$-type leaves significantly enlarged multivariate range of variation of $Z$. abelicea, but they did not form clearly distinct monotypic groups, as occurred in $Z$. carpinifolia (Jasińska et al., 2015) and Z. sicula. 
As in Z. carpinifolia (Jasińska eta al., 2015), a broader apex angle of S-type than of L-type leaves was found in $Z$. sicula but not in $Z$. abelicea. This is quite unusual and rather inconsistent with a more general rule (Jentys-Szaferowa, 1970; Wójcicki, 1997; Staszkiewicz, 1997 and literature cited herein).

Concerning the Cretan species, the NN-type leaves deserve some additional discussion. They exhibited the highest values of variation coefficients in most leaf characters, which once again could be interpreted as the direct reaction of plants to ovine and caprine overgrazing. Actually, it is likely that many of these undetermined leaves came from the largely widespread browsed specimens (Kozlowski et al., 2014; Kairis et al., 2015). Heavy browsing involves a significant reduction in leaf blade size and directly impacts the values of other diagnostic characters. In fact, only some simple qualitative/descriptive features (AA, AB, TN and NTV) or quantitative proportional characters (PV, W_1, W_2, W_3, LBW, LS) seemed to be relatively less affected by browsing. In this case, our samples including leaves with very different life-history, probably mirror the current 'anomalous' situation, i.e. the direct effects of overbrowsing. Hence, biting/browsing disturbance represents an important element of evaluation when using the morphometric approach to classify taxonomically unknown leaf samples.

\section{Variation of leaf characters and taxonomic relationships among species}

It is noteworthy that the molecular differences already pointed out among the three investigated species (Fineschi et al., 2002; Christe et al., 2014) were corroborated by the differences detected using the leaf characters of our study. In the data set we used, only one character of the leaves (W_2) did not differentiate between $Z$. carpinifolia and $\bar{Z}$. abelicea, independent of the L-, S- or NN-type leaves of the latter species. However, no leaf character considered separately proved effective to distinguish between these taxa. Simple traits, such as the length (BL) and width (BW) of the leaf blade, number of denticles (TH) and lateral veins (NVT), generally had high diagnostic values in $Z$. carpinifolia and $Z$. abelicea (Table 2), but only when used jointly allowed distinct between them, irrespective of whether the leaves were from vegetative or fruiting shoots. It should be stressed yet, that the S-type leaves of $Z$. carpinifolia are somewhat similar to the L-type leaves of $Z$. abelicea leaves.

With regard to Z. sicula, it should be pointed out that leaf morphological characters situated this species between $Z$. carpinifolia and Z. abelicea, but simultaneously emphasized the high level of multivariate differences between their two known populations. Interestingly, the characters of the S-type leaves placed both populations of $Z$. sicula close to $Z$. abelicea, whereas those of the L-type leaves separated the two Mediterranean insular relicts, but with the Sicilian species entering the $95 \%$ confidence intervals of $Z$. carpinifolia (Fig. 5B). This could be interpreted as an additional support of the probable hybrid origin of $Z$. sicula, as already suggested by Christe et al. (2014).

\section{An intriguing history of lineage separation}

Our morphometric analyses provided some interesting results concerning the geographic distinctiveness at inter- and intra-specific level of the three south-western Eurasian Zelkova species. Firstly, leaf features from vegetative shoots, and to a lesser extent also from fruiting shoots, clearly situated apart the Euxino-Hyrcanian species from the two Mediterranean taxa at least on the population level. Among the investigated species, $Z$. carpinifolia is the only one still growing under temperate and humid climatic conditions (Kvavadze \& Connor, 2005), with short dry season similar to the Cenozoic (Tertiary) subtropical environments (Mai, 1995; Kovar-Eder, 2003), where the genus originated and spread throughout Eurasia (Manchester, 1989; Akhmetiev, 2010; KanKan et al., 2016; Zhang et al., 2017). Conversely, both the insular $Z$. abelicea and $Z$. sicula occur under typical Mediterranean climates, with 3-4 months of summer drought. It can be assumed that along their evolutionary history the two Mediterranean Zelkova species developed adaptive traits, such as leaf size reduction and other associated/derived characters (Marcysiak 2012b; Pérez-Harguindeguy et al., 2013), which resulted in higher fitness to the more xeric climate experienced in their respective refugial areas. Most evidently, the discriminant value of such traits is so remarkable that on its basis the two different biogeographic units could be easily separated.

With concern to intra-specific variability, our results also emphasized the high levels of multivariate distance between the two only known populations of $Z$. sicula. This finding is consistent with the results of previous genetic investigations, which showed that the Sicilian populations have a different single plastid haplotype, so that they have been guessed as two different clones (Christe et al., 2014). This could explain the relatively low degree of intra-population variation of leaf characters detected in our study. Their separation could result of the severe isolation of each population due to the complete lack of sexual reproduction (Garfi et al., 2011). Alternatively, it possibly origins from two independent hybridization 
events, as suggested for Pinus uliginosa Neumann (Boratyńska et al., 2015). In the case of $Z$. sicula, the hybridization could take place only after the emersion of the Hyblaean Plateau (South-Eastern Sicily), between different parental individuals close to the ancestral species of $Z$. abelicea and $Z$. carpinifolia (Fineschi et al., 2002; Christe et al., 2014). Interestingly, the Hyblaean Plateau was still below sea level until early Pleistocene, when punctual uplift driven mainly by magmatic processes triggered its stepwise emergence (Henriquet et al., 2019). The Hyblaean Plateau represented an island separated from Sicily until late Pleistocene, when it was finally connected to Sicily (Longhitano \& Colella, 2003). Consequent$1 y$, both the putative ancestors of $Z$. sicula were able to colonize this area only afterwards, hence their co-occurrence, hybridization and large-scale extinction shall happened no earlier than before 2-3 MA.

The populations of $Z$. abelicea from the different mountain massifs in Crete exhibited high levels of genetic differentiation, which was explained by their long-lasting spatial isolation (Christe et al., 2014; Naciri et al., 2019). Unfortunately, in our analysis we could obtain material from only some representatives of the Cretan populations. Additionally, our material was heterogeneous because of NN-type of leaves. Despite that, the geographic trends of differentiation among populations and individuals through leaf morphometry were rather consistent with patterns issued from genetic analysis. This picture, however, needs further validation by including samples from all known populations and using leaves from the same type of shoots, as it has been done for $Z$. carpinifolia.

\section{Conclusions}

The morphological leaf characters allowed us to distinguish among Zelkova species in the Mediterranean region and south-western Asia, especially when at least 3-4 characters were used simultaneously. The leaves from vegetative long shoots appeared to be more suitable for discriminating among species than other leaf types. Also, leaf biometric analyses proved to be effective in discriminating the investigated species according to their current biogeographic range. The two known populations of the relict species Z. sicula (Garfi et al. 2021) differed from each other strongly in terms of leaf characters, but each population revealed the lowest level of phenotypic variation, probably as a result of their clonal origin. Moreover, $Z$. sicula appeared to be an intermediate between its Mediterranean relative $Z$. abelicea and the Euxino-Hyrcanian Z. carpinifolia, supporting previous hypotheses about its hybrid origin.

\section{Acknowledgments}

This work was supported by the Fondation Franklinia and by the Institute of Dendrology Polish Academy of Sciences. We thank S. Pirintsos and his team (University of Crete, Greece), Y. Marbach, D. Frey (University of Fribourg, Switzerland), and L. Keller (Lausanne, Switzerland) for their assistance during fieldwork, R. Klais (Tartu University, Estonia) for helpful statistical discussion and M. Łuczak (Institute of Dendrology, Kórnik) for technical assistance and the preparation of herbarium specimens. Permission to investigate $Z$. abelicea populations was granted by the Ministry of the Environment, General Directorate of Forests, Department of Aesthetic Forests, National Parks and Wildlife Management, Athens, Greece (199076/1843).

\section{References}

Akhmetiev MA (2010) Paleocene and Eocene floristic and climatic change in Russia and Northern Kazakhstan. Bulletin of Geosciences 85: 77-94. doi:10.3140/bull.geosci.1145.

Anşin R \& Gerçek Z (1991) Türkiye Florası İçin Yeni Bir Zelkova Taksonu. Zelkova carpinifolia (Pall.) C. Koch ssp. yomraensis Anșin \& Gerçek, ssp. nova. Doğa. Turkish Journal of Agriculture and Forestry 15: 564-575.

Boratyńska K, Jasińska AK \& Boratyński A (2015) Taxonomic and geographic differentiation of Pinus mugo complex on the needle characteristics. Systematics and Biodiversity 13: 581-595. doi:10.10 80/14772000.2015.1058300.

Bosque M, Adamogianni MI, Bariotakis M, Fazan L, Stoffel M, Garfí G, Gratzfeld J, Kozlowski G \& Pirintsos S (2014) Fine-scale spatial patterns of the Tertiary relict Zelkova abelicea (Ulmaceae) indicate possible processes contributing to its persistence to climate changes. Regional Environmental Change 14: 835-849. doi:10.1007/s10113-0130544-1.

Browicz K \& Zieliński J (1982a) Chorology of trees and shrubs in South-West Asia and adjacent regions. Polish Scientific Publishers, WarszawaPoznań.

Browicz K \& Zieliński J (1982b) Zelkova Spach.: Flora of Turkey and the East Aegean Islands (ed. by PH Davis) University Press, Edinburgh, pp. 648-649.

Christe C, Kozlowski G, Frey D, Bétrisey S, Maharramova E, Garfi G, Pirintsos S \& Naciri Y (2014) Footprints of past intensive diversification and structuring in the genus Zelkova (Ulmaceae) in south-western Eurasia. Journal of Biogeography 41: 1081-1093. doi:org/10.1111/jbi.12276. 
Christensen KI (1997) Zelkova Spach.: Flora Hellenica. Vol. 1 (ed. by A Strid \& K Tan) Koeltz Scientific Books, Königstein, Federal Republic of Germany.

Denk T \& Grimm GW (2005) Phylogeny and biogeography of Zelkova (Ulmaceae sensu stricto) as inferred from leaf morphology, ITS sequence data and the fossil record. Botanical Journal of the Linnean Society 147: 129-157. doi:org/10.1111/ j.1095-8339.2005.00354.x.

Di Pasquale G, Garfi G \& Quézel P (1992) Sur la présence d'un Zelkova nouveau en Sicile sud orientale (Ulmaceae). Biocosme Mésogéen 8-9: 401-409.

Fazan L, Stoffel M, Frey DJ, Pirintsos S \& Kozlowski G (2012) Small does not mean young: Age estimation of severely browsed trees in anthropogenic Mediterranean landscapes. Biological Conservation 153: 97-100. doi:org/10.1016/j. biocon.2012.04.026.

Fineschi S, Anzidei M, Cafasso D, Cozzolino S, Garfi G, Pastorelli R, Salvini D, Taurchini D \& Vendramin GG (2002) Molecular markers reveal a strong genetic differentiation between two European relic tree species: Zelkova abelicea (Lam.) Boissier and Z. sicula Di Pasquale, Garfí et Quézel (Ulmaceae). Conservation Genetics 3: 145-153. doi:10.1023/A:1015222230887.

Fu L, Xin Y \& Whittemore A (2003) Ulmaceae: Flora of China 5 (ed. by Z Wy \& P Raven) Missouri Botanic Garden Press, St. Louis, Illinos, USA.

Garfi G, Carimi F, Fazan L, Gristina AS, Kozlowski G, Console Livreri S, Motisi A \& Pasta S (2021) From glacial refugia to hydrological microrefugia: factors and processes driving the persistence of the climate relict Zelkova sicula. Ecology and Evolution. doi.org/10.1002/ece3.7253.

Garfi G, Carimi F, Pasta S, Rühl R \& Trigila S (2011) Additional insights on the ecology of the relic tree Zelkova sicula di Pasquale, Garfi et Quézel (Ulmaceae) after the finding of new population. Flora 206: 407-417. doi:org/10.1016/j.flora.2010.11.004.

Garfí G, Pasta S, Fazan L \& Kozlowski G (2017) Zelkova sicula. The IUCN red list of threatened species 2017: eT61678A86134112. doi:10.2305/IUCN. UK.2017-3.RLTS.T61678A86134112.en.

Garren ST (1998) Maximum likelihood estimation of the correlation coefficient in a bivariate normal model with missing data. Statistics \& Probability Letters 38: 281-288.

Goedecke F \& Bergmeier E (2018) Ecology and potential distribution of the Cretan endemic tree species Zelkova abelicea. Journal of Mediterranean Ecology 16: 15-26.

Grossheim AA (1930) Flora Kavkaza, 2. Izdatelstvo Akademii Nauk USSR, Moskva - Leningrad.

Henriquet M, Dominguez S, Barreca G, Malavieille J, Cadio C \& Monaco C (2019) Deep origin of the dome*shaped Hyblean Plateau, Southeastern Sicily: A new tectono-magmatic model. Tectonics 38: 4488-4515. doi:10.1029/2019TC005548.

Hood GM (2010) PopTools version 3.2.5. http:// www.poptools.org.

Jasińska A, Rucińska B, Kozlowski G, Bétrisey S, Safarov H, Boratyńska K \& Boratyński A (2015) Morphological differentiation of leaves in the relict tree Zelkova carpinifolia (Ulmaceae). Dendrobiology 74: 109-122. doi:10.12657/DENBIO.074.011.

Jentys-Szaferowa J (1970) Zmienność liści i owoców drzew i krzewów w zespołach leśnych Białowieskiego Parku Narodowego. Monographiae Botanicae 32: 5-238.

Kan-Kan S, Kun S \& Liang-Jun D (2016) Vegetation structure and function at multiple spatial, temporal and conceptual scales. Geobotany studies (basics, methods and case studies): Ecology of relict tertiary deciduous trees in subtropical China (ed. by E Box) Springer, Cham, pp. 149-165. doi:10.1007/978-3-319-21452-8_5.

Kairis O, Karavitis C, Salvati L, Kounalaki A \& Kosmas K (2015) Exploring the impact of overgrazing on soil erosion and land degradation in a dry Mediterranean agroforest landscape (Crete, Greece). Arid Land Research and Management 29: 360374. doi:10.1080/15324982.2014.968691.

Kovar-Eder J (2003) Vegetation dynamics in Europe during the Neogene: Distribution and migration of tertiary mammals in Eurasia (ed. by JWF Reumer \& W Wessels). DEINSEA 10: 373-392.

Kozlowski G, Frey D, Fazan L, Egli B, Bétrisey S, Gratzfeld J, Garfi G \& Pirintsos S (2014) The Tertiary relict tree Zelkova abelicea (Ulmaceae): distribution, population structure and conservation status. Oryx 48: 80-87. doi:10.1017/ S0030605312001275.

Kozlowski G \& Gratzfeld J (2013) Zelkova - an ancient tree. Global status and conservation action. Natural History Museum Fribourg, Fribourg, Switzerland.

Kozlowski G, Bétrisey S, Song YG, Fazan L \& Garfi G (2018) The red list of Zelkova. Natural History Museum Fribourg, Fribourg, Switzerland.

Krüssmann G (1962) Handbuch de Laubgehölze, 3. Paul Parey, Berlin - Hamburg.

Kvavadze EV \& Connor SE (2005) Zelkova carpinifolia (Pallas) K. Koch in Holocene sediments of Georgia - an indicator of climatic optima. Review of Palaeobotany and Palynology 133: 69-89. doi:10.1016/j.revpalbo.2004.09.002.

Lakusic B, Stevanovic B, Jancic R \& Lakusic D (2010) Habitat-related adaptations in morphology and anatomy of Teucrium (Lamiaceae) species from the Balkan peninsula (Serbia and Montenegro). Flora 205: 633-646. doi:10.1016/j.flora.2010.04.018. 
Longhitano SG \& Colella A (2003) Stratigraphy and basin-fill architecture of a Plio-Pleistocene foredeep basin (Catania Plain, eastern Sicily): A preliminary synthesis. GeoActa 1: 111-130.

Lozina-Lozinskaya AS (1951) Ulmaceae Mirb.: Derevya i kustarniki SSSR 2 (ed. by SY Sokolov) Izdatelstvo Akademii Nauk SSSR, Moskva-Leningrad, pp. 493-523.

Mai DH (1995) Tertiäre Vegetationsgeschichte Europas. Gustav Fischer, Jena.

Manchester SR (1989) Systematics and fossil history of the Ulmaceae: Evolution, systematics, and fossil history of the Hamamelidae 2 (ed. by PR Crane \& S Blackmore) Clarendon Press, Oxford, pp. 221-251.

Manni F, Guerard E \& Heyer E (2004) Geographic patterns of (genetic, morphologic, linguistic) variation: how barriers can be detected by using Monmonier's algorithm. Human Biology 76: 173190. doi:10.1353/hub.2004.0034.

Mantel N (1967) The detection of disease clustering and a generalized regression approach. Cancer Research 27: 209-220.

Marcysiak K (2012a) Calculated characters of leaves are independent on environmental conditions in Salix herbacea (Salicaceae) and Betula nana (Betulaceae). Acta Societatis Botanicorum Poloniae 81: 153-158. doi:10.5586/asbp.2012.027.

Marcysiak K (2012b) Diversity of Salix reticulata L. (Salicaceae) leaf traits in Europe and its relation to geographical position. Plant Biosystems 146: 101-111. doi:10.1080/11263504.2012.727879.

Marcysiak K (2012c) Variation of leaf shape of Salix herbacea in Europe. Plant Systematics and Evolution 298: 1597-1607. doi:10.1007/s00606-0120662-0.

Mejnartowicz L (1972) Badania zmienności populacji Alnus glutinosa (L.) Gaertn. w Polsce. Arboretum Kórnickie 17: 43-120.

Naciri Y, Christe C, Bétrisey S, Song YG, Deng M, Garfi G \& Kozlowski G (2019) Species delimitation in the East Asian species of the relict tree genus Zelkova (Ulmaceae): A complex history of diversification and admixture among species. Molecular Phylogenetics and Evolution 134: 172185. doi:10.1016/j.ympev.2019.02.010.

Nakagawa T, Garfi G, Reille M \& Verlaque R (1998) Pollen morphology of Zelkova sicula (Ulmaceae), a recently discovered relic species of the European Tertiary flora: description, chromosomal relevance, and palaeobotanical significance. Review of Palaeobotany and Palynology 100: 27-37. doi:10.1016/S0034-6667(97)00062-6.

Pérez-Harguindeguy N, Díaz S, Garnier E, Lavorel S, Poorter H, Jaureguiberry P, Bret-Harte MS, Cornwell WK, Craine JM, Gurvich DE, Urcelay C, Veneklaas EJ, Reich PB, Poorter L, Wright IJ,
Ray P, Enrico L, Pausas JG, de Vos AC, Buchmann N, Funes G, Quétier F, Hodgson JG, Thompson K, Morgan HD, Steege H, van der Heijden MGA, Sack L, Blonder B, Poschlod P, Vaieretti MV, Conti G, Staver AC, Aquino S \& Cornelissen JHC (2013) New handbook for standardised measurement of plant functional traits worldwide. Australian Journal of Botany 61: 167-234. doi:10.1071/ BT12225_CO.

Prilipko LI (1961) Zelkova Spach: Dendroflora Kavkaza 2 (ed. by VZ Gulisashvili) Institut Lesa Gruzinskoy AN, Tbilisi, pp. 308-318.

Quézel P, Di Pasquale G \& Garfi G (1993) Découverte d'un Zelkova en Sicile sud-orientale. Incidences biogéographiques et historiques. Comptes Rendus de l'Académie des Sciences 316: 21-26.

Rivas-Martínez S, Peñas Á \& Díaz González TE (2004) Bioclimatic map of Europe -Thermoclimatic belts. Cartographic Service, University of León, León. http://www.globalbioclimatics.org/ form/tb med.htm.

Rucińska B (2012) Systematyka europejskich i południowozachodnio-azjatyckich taksonów rodzaju Zelkova Spach na podstawie wielocechowej analizy liści. MSc Thesis, Faculty of Natural Sciences, Kazimierz Wielki University, Bydgoszcz, Poland.

Sarlis GP (1987) Zelkova abelicea (Lam.) Boiss., an endemic species of Crete (Greece). Webbia 41: 247255. doi:10.1080/00837792.1987.10670412.

Shapiro SS \& Wilk MB (1965) An analysis of variance test for normality (complete samples). Biometrika 52: 591-611. doi:10.1093/biomet/52.3-4.591.

Sokal RR \& Rohlf FJ (1995) Biometry. The principles and practice of statistics in biological research. 3rd ed. W. H. Freeman and Co., New York.

Søndergaard P \& Egli BR (2006) Zelkova abelicea (Ulmaceae) in Crete: floristics, ecology, propagation and threats. Willdenowia 36: 317-322. doi:10.3372/wi.36.36126.

Stanisz A (2007) Przystępny kurs statystyki z zastosowaniem STATISTICA PL na przykładach $z$ medycyny, 2. Modele liniowe i nieliniowe, 3. Analizy wielowymiarowe. StatSoft, Kraków.

Staszkiewicz J (1997) Zmienność wybranych gatunków drzew i krzewów. Fragmenta Floristica et Geobotanica, Polonica, Suppl. 2.

Tutin TG (1964) Zelkova Spach: Flora Europaea 1 (ed. by TG Tutin, VH Heywood, NA Burges, DH Valentine, SN Walters \& DA Web) Cambridge University Press, Cambridge.

Wang YF, Ferguson DK, Zetter R, Denk T \& Garfi G (2001) Leaf architecture and epidermal characters in Zelkova, Ulmaceae. Botanical Journal of the Linnean Society 136: 255-265. doi:10.1111/j.1095-8339.2001.tb00571.x. 
Wójcicki JJ (1997) Zmienność liści olszy zielonej Alnus viridis (Betulaceae). Fragmenta Floristica et Geobotanica, Polonica, Suppl 2: 5-13.

Zar JH (1999) Biostatistical analysis. Prentice Hall, New Jersey.

Zhang ML, Wang L, Lei Y \& Sanderson SC (2017) Cenozoic evolutionary history of Zelkova (Ulmaceae), evidenced from ITS, trnL-trnF, psbA-trnH, and rbcL. Tree Genetics \& Genomes 13: e101. doi:10.1007/s11295-017-1182-4.

Zhong M, Wang J, Liu K, Wu R, Liu Y, Wei X, Pan D \& Shao X (2014) Leaf morphology shift of three dominant species along altitudinal gradient in an alpine meadow of the Qinghai-Tibetan Plateau. Polish Journal of Ecology 62: 639-648. doi:10.3161/104.062.0409.

Zieliński J (1979) Ulmaceae: Flora Iranica 142 (ed. by KH Rechinger) Akademische Druck und Vermagsanstalt, Graz.

Zieliński J \& Güner A (2000) Flora of Turkey and East Aegean Islands, 11 (Suppl. 2): Zelkova Spach (ed. by A Güner, N Özhatay, T Ekim \& KHC Başer) Edinbourgh University Press, Edinbourg. 